\title{
Author's response: False-positive results with rapid diagnostic test for dengue in Thailand
}

Anu Kantele ${ }^{1}$

1. Professor of Infectious Diseases, Inflammatory Center, Helsinki University Hospital and Helsinki University

Correspondence: Anu Kantele (anu.kantele@hus.fi)

Citation style for this article:

Kantele Anu. Author's response: False-positive results with rapid diagnostic test for dengue in Thailand. Euro Surveill. 2019;24(21):pii=1900309. https://doi. org/10.2807/1560-7917.ES.2019.24.21.1900309

Article submitted on 20 May 2019 / accepted on 23 May 2019 / published on 23 May 2019

I thank Javelle et al. for the methodological remarks [1] they made about my recent paper describing a cluster of chikungunya cases among visitors to Thailand [2]. Their letter concerns the positive dengue rapid diagnostic test (RDT) results recorded for two of our patients at the local hospital at their holiday destination. Unfortunately, no details are available on the RDT that was used, yet-as Javelle et al. point out-those commonly applied in dengue diagnostics lack sensitivity and specificity [3].

The dengue virus (DENV) IgG determination carried out at HUSLAB, Helsinki University Hospital, which is responsible for most of the dengue diagnostics in Finland, is based on an in-house immunofluorescence assay (IFA) that, together with a commercial IgM EIA testing, would have shown DENV antibody response at the time of sampling in Finland [4]. Moreover, the IgG test is strongly cross-reactive between flaviviruses. An early case of congenital Zika virus (ZIKV) infection, for example, has been identified using this DENV-IgGIFA test [5]. Similar IgG titres are typically obtained for both the DENV and ZIKV antigens, regardless of the infecting virus [6]. Strong cross-reactivity is also seen with other mosquito-borne flaviviruses. For these reasons, I am confident that the negative DENV-IgG IFA results rule out a recent mosquito-borne flavivirus, particularly DENV or ZIKV infection, confirming that the patients did not have a DENV/ZIKV co-infection with CHIKV. Nevertheless, clinicians should be reminded about the possibility of co-infections with ZIKV, DENV and CHIKV, as they all cause broadly similar symptoms and circulate in the same areas $[7,8]$.

\section{Acknowledgments}

The author thanks professor Olli Vapalahti (University of Helsinki and HUSLAB, Helsinki University Hospital) for expert help in drafting the reply.
Conflict of interest

None declared.

Authors' contributions

AK wrote the manuscript.

\section{References}

1. Javelle E, Gautret P, Leparc-Goffart I. Letter to the editor: False positive results with rapid diagnostic tests (RDT) for dengue. Euro Surveill. 2019;24(21):1900304. Forthcoming.

2. Kantele A. Travellers as sentinels of chikungunya epidemics: a family cluster among Finnish travellers to Koh Lanta, Thailand, January 2019. Euro Surveill. 2019;24(11):1900162. https:// doi.org/10.2807/1560-7917.ES.2019.24.11.1900162 PMID: 30892179

3. Hunsperger EA, Yoksan S, Buchy P, Nguyen VC, Sekaran SD, Enria DA, et al. Evaluation of commercially available diagnostic tests for the detection of dengue virus NS1 antigen and anti-dengue virus IgM antibody. PLoS Negl Trop Dis. 2014;8(10):e3171. https://doi.org/10.1371/journal. pntd.0003171 PMID: 25330157

4. Erra EO, Korhonen EM, Voutilainen L, Huhtamo E, Vapalahti 0 , Kantele $A$. Dengue in travelers: kinetics of viremia and NS1 antigenemia and their associations with clinical parameters. PLoS One. 2013;8(6):e65900. https://doi.org/10.1371/journal. pone.0065900 PMID: 23755291

5. Driggers RW, Ho CY, Korhonen EM, Kuivanen S, Jääskeläinen A), Smura T, et al. Zika virus infection with prolonged maternal viremia and fetal brain abnormalities. $N$ Engl J Med. 2016;374(22):2142-51. https://doi.org/10.1056/ NEJMoa1601824 PMID: 27028667

6. Jääskeläinen AJ, Korhonen EM, Huhtamo E, Lappalainen M, Vapalahti O, Kallio-Kokko H. Validation of serological and molecular methods for diagnosis of zika virus infections. I Virol Methods. 2019;263:68-74. https://doi.org/10.1016/j. jviromet.2018.10.011 PMID: 30342068

7. Furuya-Kanamori L, Liang S, Milinovich G, Soares Magalhaes RJ, Clements AC, Hu W, et al. Co-distribution and co-infection of chikungunya and dengue viruses. BMC Infect Dis. 2016;16(1):84. https://doi.org/10.1186/s12879-016-1417-2 PMID: 26936191

8. Waggoner JJ, Gresh L, Vargas MJ, Ballesteros G, Tellez Y, Soda $\mathrm{KJ}$, et al. Viremia and clinical presentation in Nicaraguan patients infected with zika virus, chikungunya Virus, and dengue virus. Clin Infect Dis. 2016;63(12):1584-90. https://doi. org/10.1093/cid/ciw589 PMID: 27578819 
License, supplementary material and copyright

This is an open-access article distributed under the terms of the Creative Commons Attribution (CC BY 4.0) Licence. You may share and adapt the material, but must give appropriate credit to the source, provide a link to the licence and indicate if changes were made.

Any supplementary material referenced in the article can be found in the online version.

This article is copyright of the authors or their affiliated institutions, 2019. 